\title{
Muscular cysticercosis: Case report and imaging findings
}

\author{
Neide Regina Simões Olmo ${ }^{1,2 *}$, Ulysses Ferreira Fiorio ${ }^{1}$, Eder Amaral Bastos ${ }^{3,4}$, Marcel Andreazza Clemente $^{5}$, \\ Gustavo Gomes Mendes ${ }^{6}$ \\ ${ }^{1}$ Radiology Trainee at Clínica Mult Imagem, Santos, SP, Brazil \\ ${ }^{2} \mathrm{PhD}$ in Sciences from Faculdade de Medicina da Universidade de São Paulo (FMUSP), São Paulo, SP, Brazil \\ ${ }^{3} \mathrm{MD}$, Specialist Degree in Radiology and Diagnostic Imaging from Colégio Brasileiro de Radiologia e Diagnóstico por Imagem (CBR)/Associação Médica Brasileira (AMB), São Paulo, SP, Brazi \\ ${ }^{4} \mathrm{MSc}$ Student, Masters in Health and Environment from Universidade Metropolitana de Santos (Unimes), Santos, SP, Brazil \\ ${ }^{5}$ Medical Coordinator at Clínica Mult Imagem, Santos, SP, Brazil \\ ${ }^{6}$ Full Member of the Imaging Department at A.C.Camargo Cancer Center, São Paulo, SP, Brazi
}

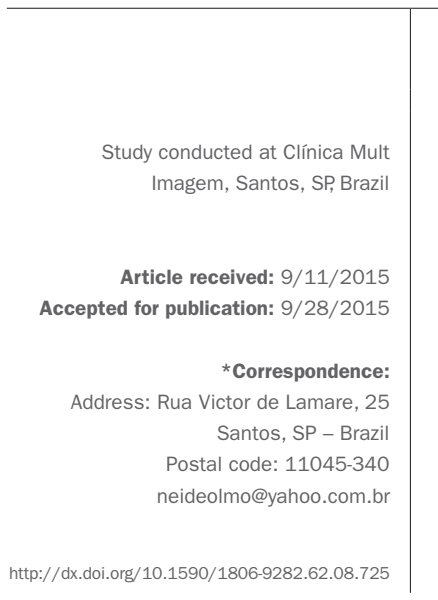

\section{SUMMARY}

Cysticercosis is a parasitic disease caused by a worm of the Cestoda class. The most prevalent form affects the nervous system. This case report is from a 78-yearold female patient evaluated at Clínica Mult Imagem, in the city of Santos, Brazil, who presented a form of the disease that differed from the classic neurocysticercosis, in this case muscular cysticercosis. This and other forms of manifestation justify further studies to ensure adequate recognition, diagnosis and treatment of this parasitic disease.

Keywords: muscular cysticercosis, Taenia solium, Taenia saginata, parasitosis, hip arthroplasty.

\section{INTRODUCTION}

The incidence of cysticercosis in Latin America is high. The most prevalent clinical form is that with intracranial location. ${ }^{1}$ Due to migration flows, cysticercosis transcends borders, invades systems, and reaches new territories. $^{2}$

In the imaging service of Clínica Mult Imagem, located in the city of Santos, we are faced with a case of muscular cysticercosis.

This is a case report obtained from imaging studies performed in March 2015. A computed tomography (CT) scan subjected to analysis at Clínica Mult Imagem revealed the presence of numerous riziform calcifications in muscle tissue of a patient.

Since this is not a form of cysticercosis prevalent in our country, we report this case for the purpose of study and image observation.

\section{Case report}

IRB, 78 years old, female, Brazilian, married, born in the São Paulo state capital, a resident of the city of Peruíbe, referred to Clínica Mult Imagem for a CT with complaint of pain in the topography of left femoral hip prosthesis. A mult-slice CT scan with image acquisition through volumetric sequences without intravenous contrast administration showed: “(...) Numerous foci of riziform calcifications ('rice grains') spread over all the muscle groups of the pelvis and thigh, leading to the main diagnostic hypothesis of muscular cysticercosis (...)" (Figures 1,2 , and 3).

\section{Discussion}

Teniasis and cysticercosis, although caused by a worm of the Cestode class, refer to different stages of the life cycle of these parasites. The worm that lodges in the small intestine of the definitive host (human being) is the adult form of Taenia solium or Taenia saginata. Cysticercosis, in turn, is caused by the presence of the parasite in its larval stage in tissues of intermediate hosts (pork and cattle). In cysticercosis, man is an accidental intermediate host due to poor habits of hygiene, poor sanitation, and improper preparation and cooking of food. ${ }^{3}$

Clinical manifestations vary according to the affected system. Regarding muscular cysticercosis, we can mention some signs/symptoms classified in the literature as types: myalgia, appearance of nodules or pseudomasses, and muscle pseudohypertrophy. ${ }^{2}$

On X-ray, depending on the stage of the parasite, riziform calcifications or a "starry sky" can be identified. ${ }^{2}$

On ultrasound, anechoic lesions and scolices can be identified. The literature cites four types of sonographic findings: 1 . cyst with surrounding inflamma- 
tory mass resulting from the larval death; 2 . irregular cyst with minimal fluid and indication of leakage, as well as scolex; 3 . large irregular collection of exudative fluid, with scolex within it, resembling an abscess; 4. calcified cysticerci, with the identification of multiple elliptical calcifications. ${ }^{8}$

On MRI, cysts can be described along the muscles' fibers, presenting hyposignal on T1-weighted sequence, and hypersignal on T2-weighted sequences. ${ }^{2,7}$

\section{Conclusion}

Cysticercosis, as a subject, although linked to tropical medicine, reaches other regions due to migratory flows and cultural habits that arise from these flows, ceasing to be restricted to/exclusive of the poorest countries.

The interest and importance of this report relate to correct diagnosis for the benefit of patients and appropriate treatment, minimizing time and public spending, avoiding mistakes and introducing appropriate treatment.

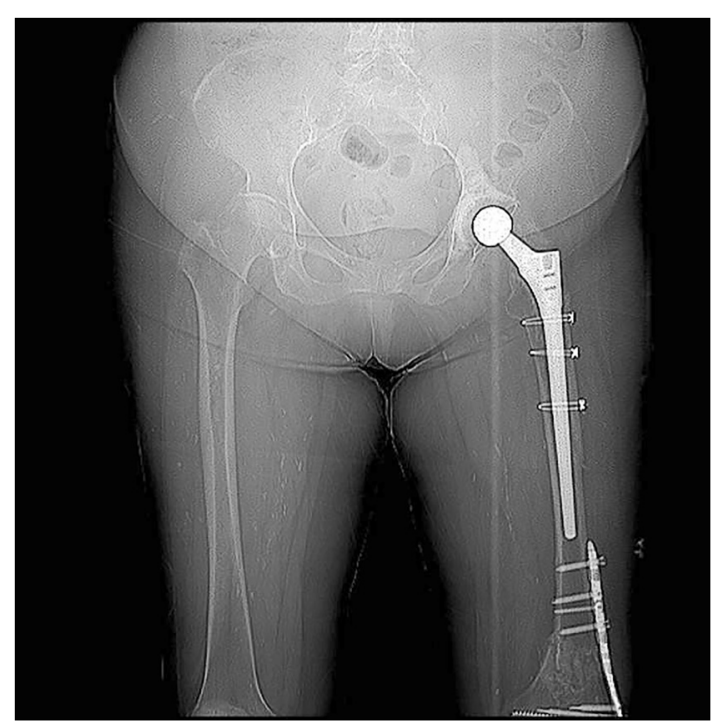

FIGURE 1 Panoramic X-ray showing numerous radiopaque riziform images in the soft tissues of the thighs.

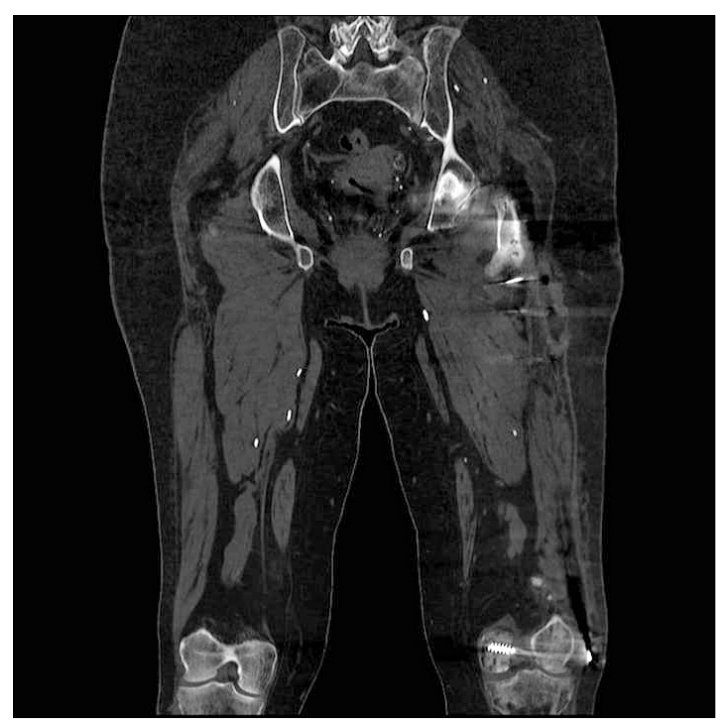

FIGURE 2 Coronal view of multi-slice CT scan showing calcifications in the muscle groups of the thighs in more detail. 


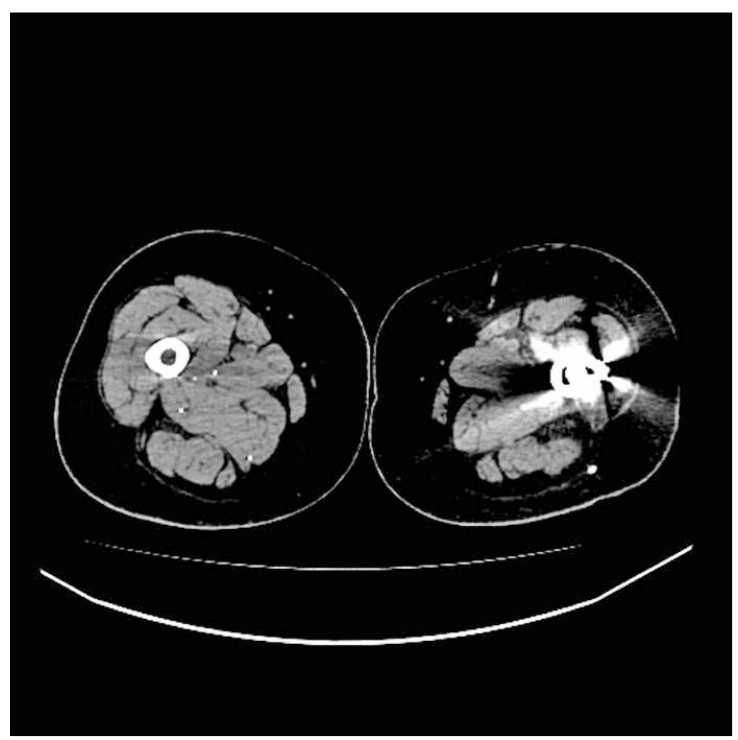

FIGURE 3 Axial slice showing calcifications related to cysticercosis.

The image-based investigation plays a key role in correct diagnosis.

\section{Resumo}

Cisticercose muscular: relato de caso e aspectos de imagem

A cisticercose é uma parasitose causada pela classe Cestoda. A forma mais prevalente acomete o sistema nervoso. Este relato de caso, obtido da Clínica Mult Imagem, em Santos, é de uma paciente do sexo feminino de 78 anos que apresentou uma forma diversa de neurocisticercose, a muscular. Outras formas de manifestação da doença, como a apresentada neste relato, justificam a realização de mais estudos para assegurar o reconhecimento, o diagnóstico e o tratamento adequados dessa parasitose.
Palavras-chave: cisticercose muscular, Taenia solium, Taenia saginata, parasitose, artroplastia de quadril.

\section{References}

1. Vianna LO, Macedo V, Costa JM. Cisticercose musculo cutânea e Visceral doença rara? Rev Inst Med Trop S Paulo. 1991; 33(2):129-36.

2. Liu H, Juan $Y H$, Wang W, Liang C, Zhou H, Ghonge NP, et al. Intramuscular cysticercosis: starry sky appearance. QJM. 2014; 107(6):459-61.

3. Lino Jr RS, Reis MA, Teixeira VPA. Ocorrência de cisticercose (Cysticerus cellulosae) encefálica e cardíaca em necropsias. Rev Saúde Pública. 1999; 33(5):495-8.

4. Arriola CS, Gonzalez AE, Gomez-Puerta LA, Lopez-Urbina MT, Garcia HH, Gilman RH. New insights in cysticercosis transmission. PLoS Negl Trop Dis. 2014; 8(10):e3247.

5. Chaudhary S. Cysticercosis of deltoid muscle. BMJ Case Rep. 2014; 2014:bcr2014204578

6. Singh RP. Intramuscular cysticercosis - the solitary reaper. Ann Afr Med. 2014; 13(1):53-4.

7. Vijayaraghavan SB. Sonographic appearances in cisticercosis. J Ultrasound Med. 2004; 23(3):423-7.

8. Asrani A, Morani A. Primary sonographic diagnosis of disseminated muscular cysticercosis. J Ultrasound Med. 2004; 23(9):1245-8. 